\title{
Perilaku Ibu Terhadap Pertumbuhan Balita Dalam Permasalahan Stunting Dan Pencegahannya Di Desa Torosiaje Jaya
}

\author{
Rustam I. Husain ${ }^{1}$, Masri Kudrat Umar ${ }^{2}$, Nina Lamatenggo ${ }^{3}$ \\ Universitas Negeri Gorontalo Jl. Jend. Sudirman No.6, Dulalowo Tim., Kota Tengah, Kota Gorontalo, \\ Gorontalo 96128, Indonesia \\ Email: irdafentrianisaputri@gmail.com
}

\begin{abstract}
ABSTRAK
Proses pertumbuhan yang dialami oleh balita merupakan hasil kumulatif sejak balita tersebut dilahirkan Dari berbagai penelitian tentang stunting dan literatur yang ada diketahui bahwa selain infeksi stunting berhubungan juga dengan defisiensi gizi (mikronutrien dan makronutrien). Terdapat beberapa zat gizi yang berkaitan dengan stunting seperti protein, zat besi, zink, kalsium, dan vitamin $D, A$ dan C. 8 Selain itu, faktor hormon, genetik dan rendahnya pengetahuan orangtua dalam pengasuhan, kemiskinan, rendahnya sanitasi lingkungan, rendahnya aksesibilitas pangan pada tingkat keluarga terutama pada keluarga miskin, rendahnya akses keluarga terhadap pelayanan kesehatan dasar, dan masih terjadi disparitas antar provinsi yang perlu mendapat penanganan masalah yang sifatnya spesifik di wilayah rawan.6,9,10 Stunting merupakan indikator yang sensitif untuk sosial ekonomi yang buruk dan prediktor untuk morbiditas serta mortilitas jangka panjang. Stunting pada anak usia dini itu bersifat reversible.11

Kata Kunci: Stunting, Pengabdian,
\end{abstract}

\begin{abstract}
The growth process experienced by toddlers is a cumulative result since the toddler was born. From various studies on stunting and existing literature it is known that in addition to infection, stunting is also associated with nutritional deficiencies (micronutrients and macronutrients). There are several nutrients related to stunting such as protein, iron, zinc, calcium, and vitamins $D, A$ and $C$. at the family level, especially for poor families, low family access to basic health services, and disparities between provinces that need to be addressed specifically for problems in vulnerable areas.6,9,10 Stunting is a sensitive indicator for poor socioeconomic conditions and predictors for long-term morbidity and mortality. Stunting in early childhood is reversible. 11
\end{abstract}

Keywords: Stunting, Community Service

(C) 2019 Rustam I. Husain, Masri Kudrat Umar, Nina Lamatenggo Under the license CC BY-SA 4.0 Correspondence author: Rustam I. Husain, irdafentrianisaputri@gmail.com, Gorontalo, Indonesi 


\section{PENDAHULUAN}

Proses pertumbuhan yang dialami oleh balita merupakan hasil kumulatif sejak balita tersebut dilahirkan. Keadaan gizi yang baik dan sehat pada masa balita (umur bawah lima tahun) merupakan fondasi penting bagi kesehatannya di masa depan. Kondisi yang berpotensi mengganggu pemenuhan zat gizi terutama energi dan protein pada anak akan menyebabkan masalah gangguan pertumbuhan (Hermina \& Prihatini, 2011). oleh sebab itu, pembangunan kesehatan sangat terkait dan dipengaruhi oleh aspek demografi, keadaan dan pertumbuhan ekonomi masyarakat termasuk tingkat pendidikannya serta keadaan dan perkembangan lingkungan, baik fisik maupun biologic. Stunting atau balita pendek adalah balita dengan masalah gizi kronik, yang memiliki status gizi berdasarkan panjang atau tinggi badan menurut umur balita jika dibandingkan dengan standar baku WHO-MGRS (Multicentre Growth Reference Study) tahun 2005, memiliki nilai z-score kurang dari -2SD dan apabila nilai z-scorenya kurang dari-3SD dikategorikan sebagai balita sangat pendek (Pusdatin, 2015). Stunting terjadi mulai janin masih dalam kandungan dan baru nampak saat anak berusia dua tahun. Permasalahan Stunting merupakan isu baru yang berdampak buruk terhadap permasalahan gizi di Indonesia karena mempengaruhi fisik dan fungsional dari tubuh anak serta meningkatnya angka kesakitan anak, bahkan kejadian stunting tersebut telah menjadi sorotan WHO untuk segera dituntaskan(Kania, 2015).

Dari berbagai penelitian tentang stunting dan literatur yang ada diketahui bahwa selain infeksi stunting berhubungan juga dengan defisiensi gizi (mikronutrien dan makronutrien). Terdapat beberapa zat gizi yang berkaitan dengan stunting seperti protein, zat besi, zink, kalsium, dan vitamin D, A dan C. 8 Selain itu, faktor hormon, genetik dan rendahnya pengetahuan orangtua dalam pengasuhan, kemiskinan, rendahnya sanitasi lingkungan, rendahnya aksesibilitas pangan pada tingkat keluarga terutama pada keluarga miskin, rendahnya akses keluarga terhadap pelayanan kesehatan dasar, dan masih terjadi disparitas antar provinsi yang perlu mendapat penanganan masalah yang sifatnya spesifik di wilayah rawan.6,9,10 Stunting merupakan indikator 
yang sensitif untuk sosial ekonomi yang buruk dan prediktor untuk morbiditas serta mortilitas jangka panjang. Stunting pada anak usia dini itu bersifat reversible. 11

Prevalensi stunting di Indonesia menempati peringkat kelima terbesar di dunia ( Jakarta,TNPKK:2017). Data Riset kesehatan dasar (Riskesdas) tahun 2013 menunjukkan prevalensi stunting dalam lingkup nasional sebesar 37,2 persen, terdiri dari prevalensi pendek sebesar 18,0 persen dan sangat pendek sebesar 19,2 persen. Stunting dianggap sebagai masalah kesehatan masyarakat yang berat bila prevalensi stunting berada pada rentang 30-39 persen. Hal ini menunjukkan bahwa Indonesia sedang mengalami masalah kesehatan masyarakat yang berat dalam kasus balita stunting (RIKESDES, KEMENKES RI :2013). Penelitian ini bertujuan untuk mengentaskan kasus stunting di Desa Torosiaje Jaya,Kecamatan Popayato, Kabupaten Pohuwato.

\section{METODE PELAKSANAAN}

Jenis penelitian ini ada beberapa tahapan yang dilakukan dalam program pengabdian masyarakat mulai dari bulan September 2020 sampai dengan selesai. Penelitian ini dilaksanankan di Desa Torosiaje Jaya Kecamatan Popayato. Sampel pada penelitian ini berjumlah 29 balita. Balita belum bisa dilakukan wawancara atau recall 24 jam, sehingga wawancara dilakukan pada ibu balita yang merupakan responden penelitian. Artikel ini menggunakan Metode data sekunder. Data sekunder adalah data yang diperoleh melalui buku, bukti yang telah ada, atau arsip baik yang dipublikasikan maupun yang tidak dipublikasikan secara umum. Metode ini lebih mudah di dapatkan dan menghemat waktu pengerjaan. Dalam perihal data sekunder yang telah dikonfirmasi dari Pemerintahan Desa Torosiaje Jaya. Data survey terbaru dilaksanakan pada tahun 2020. 




Kunjungan peneliti ke Kantor Desa Torosiaje Jaya adalah untuk bertemu dengan Kepala Desa, dan Kader di desa Torosiaje Jaya, Kec. Popayato, Kab. Pohuwato untuk menyampaikan maksud kunjungan. Pada tahap ini, peneliti juga sekaligus mengidentifikasi masalah yang dihadapi oleh KPM. KPM menerima kunjungan dan melakukan diskusi mengenai permasalahan masyarakat terhadap masalah stunting. Berdasarkan keterangan kader, masyarakat masih belum maksimal dalam mengupayakan pencegahan stunting.

Identifikasi masalah didapatkan setelah melakukan diskusi dengan Kepala Desa, ahli gizi dan KPM.Penetapan solusi dan perancangan kegiatan pengabdian masyarakat yang disampaikan oleh Ahli Gizi, yang melibatkan 
KPM dan Mahasiswa KKN Tematik UNG 2020 dengan sasaran ibu hamil dan orang tua balita. Pelaksanaan kegiatan pengabdian masyarakat:penyuluhan mengenai stunting: pengertian, penyebab, dampak dan intervensi yang harus dilakukan, penyuluhan mengenai smart parenting/smart education stunting, penyuluhan mengenai kebersihan lingkungan/keindahan lingkungan.

\section{HASIL DAN PEMBAHASAN}

Kegiatan yang akan dilakukan merupakan bentuk solusi yang ditawarkan terhadap isu Stunting di Desa Torosiaje Jaya dengan sasaran para Ibu dengan anak stunting. Kegiatan pengabdian masyarakat ini memiliki tujuan untuk mengatasi masalah gizi yang dialami oleh anak di Desa Torosiaje Jaya, yang berpengaruh pada peningkatan derajat kesehatan gizi anak. Bentuk kegiatannya penyuluhan mengenai stunting, penyuluhan mengenai smart parenting/smart education stunting, dan penyuluhan mengenai kebersihan lingkungan/keindahan lingkungan.

Pada minggu pertama, kami melakukan kordinasi dengan pihak aparat desadan kader dan ibu untuk menentukan waktu pelaksanaan. Minggu kedua merupakan kegiatan penyuluhan yang dikemas dalam betuk kegiatan workashop. Kegiatan dimulai dengan memberikan materi mengenai stunting yang membahas pengertian stunting, penyebabnya, dampak kerusakan yang diakibatkan oleh stunting pada anak, dan intervensi untuk menangani kasus stunting. Selanjutnya materi kedua, penyuluhan mengenai smart parenting/smart education stunting, dan diakhiri dengan materi penyuluhan kebersihan lingkungan/keindahan lingkungan.

Kegiatan penyuluhan stunting yang kemudian masyarakat sangat berantusias untuk mengikuti kegiatan penyuluhan tersebut. Karena dalam pelaksaaan KKN ini disambut dengan sangat baik oleh warga masyarakat Jambu, sehingga setiap kegiatan program kerja utama maupun individu mendapat feed back yang baik dari masyarakat. Pada kegitan penyuluhan ini pesertanya terdiri dari ibu hamil dan orang tua balita. Selama kegiatan berlangsung ibu hamil dan orang tua balita berpartisipasi secara aktif. Pada akhir kegiatan di tutup dengan pemberian bingkisan kepada peserta. 
Kasus stunting di Desa Torosiaje Jaya sudah sangat menurun yang data dilihat dari hasil pendataan Stunting oleh KPM.

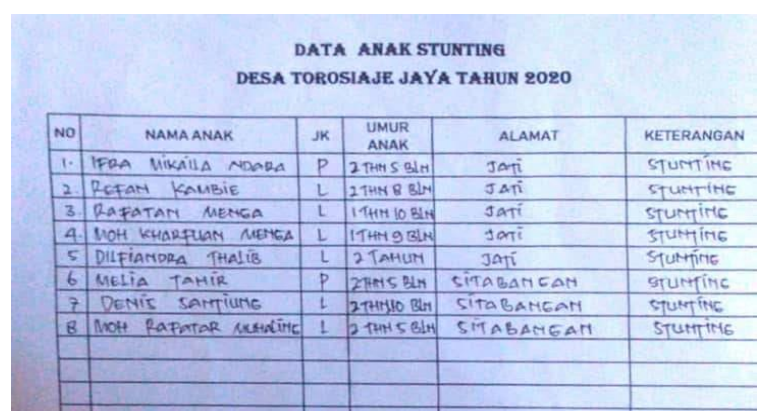

Gambar 1.1 Data Stunting

Desa Torosiaje Jaya

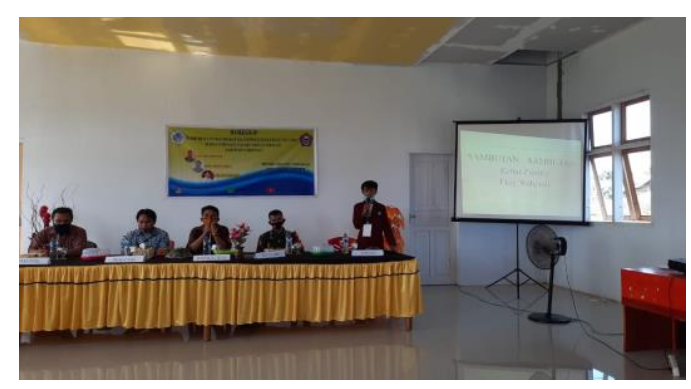

Gambar 1.2 Penyuluhan Stunting

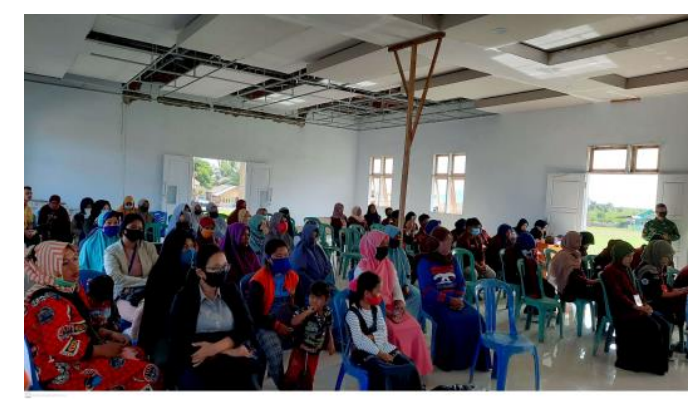

Gambar 1.3 Potret Peserta Penyuluhan

Hal yang dapat dilakukan pada ibu hamil demi mencegah terjadinya stunting pada anak antara lain:

1) Memperbaiki gizi ibu hamil, Memperbaiki gizi dan kesehatan ibu hamil merupakan cara terbaik dalam mengatasi stunting.

2) Konsumsi suplemen khusus untuk ibu hamil, Setiap ibu hamil wajib melakukan pemeriksaan rutin selama masa kehamilan kepada tenaga kesehatan yang disebut sebagai antenatal care 
3) Menjaga kesehatan diri, Selama kehamilan, Anda yang tengah hamil harus menjaga kesehatan agar tidak jatuh sakit. Menurut Kemenkes, stunting juga bisa dicegah dengan perilaku hidup bersih dan sehat serta akses memadai terhadap air bersih dan kebersihan lingkungan.

\section{KESIMPULAN}

Kesimpulan pada program pengabdian yang berujudul "Pemberdayaan Masyarakat Dalam Program Pengentasan Kasus Stunting Di Desa Torosiaje Jaya, Kecamatan Popayato, Kabupaten Pohuwato", dapat disimpulkan berjalan dengan baik, karena dalam pelaksaaan KKN ini disambut dengan sangat baik oleh warga masyarakat torosiaje, sehingga setiap kegiatan program kerja utama maupun individu mendapat feed back yang baik dari masyarakat, sehingga peserta memahami dengan saksama mengenai pengertian, penyebab, dampak dan intervensi untuk stunting. Peserta memahami dengan saksama mengenai smart parenting/smart education stunting. Peserta memahami dengan seksama mengenai kebersihan lingkungan/keindahan lingkungan.

\section{UCAPAN TERIMA KASIH}

Dalam penyusunan jurnal pengabdian yang sangat sederhana ini, Penulis mendapatkan bantuan berbagai pihak baik pemerintah maupun masyarakat desa torosiaje jaya, Untuk itu penul/is mengucapkan terimah kasih banyak kepada Bapak Dr. Rustam Husain, S.Ag., M.Pd. Selaku Dosen pembimbing lapangan dan Kepala Desa Beserta seluruh aparatur desa Torosiaje Jaya Kecamatan Popayato Kabupaten Pohuwato yang telah membantu dan membimbing Mahasiswa KKN Tematik UNG. Akhirnya ucapan terimah kasih disampaikan kepada semua pihak yang tidak dapat disebutkan satu persatu.

\section{REFERENCES}

Badan Penelitian dan Pengembangan Kesehatan Kementerian Kesehatan RI. Riset kesehatan dasar (Riskesdas). Jakarta: Balitbang Kemenkes Rl; 2013. 
Kementerian Kesehatan RI. 2015. Rencana Strategis Kementerian Kesehatan Tahun 2015-2019 (Kemenkes RI No HK.02.02/Menkes/52/2015). Jakarta.

Kementerian Kesehatan RI. Peraturan menteri kesehatan republik indonesia nomor 39 tahun 2016 tentang pedoman penyelenggaran program Indonesia sehat. Jakarta: Kemenkes Rl; 2016.

Kementerian Perencanaan Pembangunan Nasional/ Badan Perencanaan Pembangunan Nasional. Rencana aksi nasional pangan dan gizi 20062010. Jakarta; 2007.

Ratoyo.(2019). Strategi Pemberdayaan Masyarakat Dalam Penanganan Kasus Stunting Di Kampung Tulung Kakan Kecamatan Bumi Ratu Nuban Kabupaten Lampung Tengah. Jurnal Stunting

Trihono, Atmarita, Tjandrarini $\mathrm{DH}$, Irawati $\mathrm{A}$, Utami $\mathrm{NH}$, Tejayanti $\mathrm{T}$, et al. Pendek (stunting) di Indonesia, masalah dan solusinya. Jakarta: Lembaga Penerbit Balitbangkes; 2015 